Andrzej R. Hołasek (Łódź)

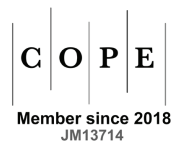

Andrej R. Holasek (Lódz)

\title{
Catechumens in the EAst in the Light of Pseudo-epigraphic Normative Church Sources FROM THE $4^{\text {TH }}$ CENTURY*
}

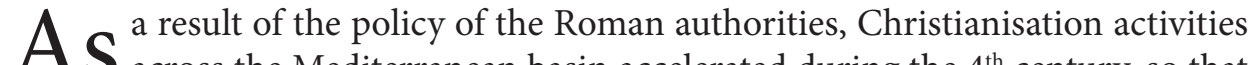
$\mathrm{AS}$ across the Mediterranean basin accelerated during the $4^{\text {th }}$ century, so that the number of people who wanted to join the Christian Church increased rapidly. We know little about the circumstances in which these conversions occurred ${ }^{1}$; what we do know, however, are the criteria and procedures associated with the preparations of those wishing to receive baptism. The candidates were called catechumens

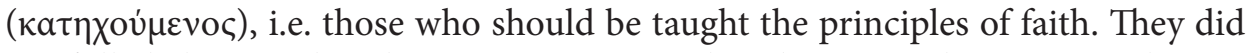
not fully belong to the Christian community, but they were also not entirely outside of $i^{2}$. Their status and the associated limitations were regulated by Church rules, including those written by pseudo-epigraphic Canon authors. In what follows, we shall analyse the so-called Canons of Hippolytus ${ }^{3}$ and Apostolic Constitutions $^{4}$ in order to see what requirements were imposed on the catechumens by the authors of these collections.
\end{abstract}

\footnotetext{
* The present paper is based on research made possible by the doctoral stipend Etiuda 4, awarded by the National Science Centre, Poland (decision no. DEC-2016/20/T/HS3/00414).

${ }^{1}$ Ewa Wipszycka (Storia della Chiesa nella tarda antichità, trans. V. Verdiani, Milano 2000, p. 62-83) presents an overview of the Christianisation of the Mediterranean world between the $3^{\text {rd }}$ and $4^{\text {th }}$ century.

${ }^{2}$ Cf. A. Laurentin, M. Dujarier, Catéchuménat. Données de l'histoire et perspectives nouvelles, Paris 1969; G. Groppo, L'evoluzione del catechumenato nelle Chiesa dal punto di vista pastorale, [in:] Valori attuali della catechesi primitiva, ed. S. FeLICI, Roma 1979, p. 29-49.

${ }^{3}$ Les Canons d'Hippolyte, ed. et trans. R.-G. Coquin, Paris 1966 [= PO, 31.2] (cetera: Can. Hipp.), p. 339-427. On this collection of regulations, cf. R.-G. Coquin, Introduction, [in:] Les Canons d'Hippolyte..., p. 273-276.

${ }^{4}$ Les Constitutions Apostoliques, vol. I-III, ed. et trans. M. Metzger, Paris 1985-1987 [= SC, 320, 329, 336], (cetera: Const. ap.). On Apostolic Constitutions cf. M. Metzger, Introduction, [in:] Les Constitutions Apostoliques, vol. I... [= SC, 320], p. 13-93; J.G. Mueller, L'ancien Testament dans l'ecclésiologie des Pères. Une lecture des Constitutions Apostoliques, Turnhout 2004, p. 35-136.
} 


\section{Catechumens in Egypt}

We learn a lot about the process of accepting catechumens into the Egyptian Church - as well as about the demands that were made of them - from the Canons of Hippolytus, whose author used the Apostolic Tradition as the basis for his work. He did not copy its Canons word for word, however; instead, he adapted them to the contemporary circumstances. In Canon 10, the author advises bishops to maintain vigilance in order to ensure that the candidates are seeking to become Christians out of true faith, rather than for other reasons ${ }^{5}$. From the Canons of Hippolytus, we learn that the first stage of the catechumenate consisted of an 'interview' designed to establish the candidate's intentions and occupation ${ }^{6}$. Subsequently, a deacon would provide the candidate with an introductory instruction concerning the principles of the faith. From that moment onwards, the person was considered a catechumen and was allowed to participate in the liturgy of the Word. Pseudo-Hippolytus does not describe the ceremony accompanying the acceptance of the candidate into the catechumenate, nor does he state how long this period of instruction should last. In any case, this stage was of great importance, since it shaped the new habits associated with professing the Christian faith. The Canons of Hippolytus inform us that the catechumens were expected to begin adjusting their lives to the principles they were learning.

The first expression of this process was to be the abandoning of an inappropriate occupation or profession. The aim was to prevent the candidates from defiling themselves with activities that contradicted the Christian faith and morality. For this reason, in Canon 12, the author enumerates the professions in which no catechumen or baptised faithful should be engaged. These included acting (likely also dancing and pantomime), professional sports (associated with participation in games), teaching to play musical instruments, membership in an orchestra (perhaps due to links with ceremonies of pagan cults or games), being a gladiator, hunting, training horses (likely because of chariot races in the hippodrome), and serving as a pagan priest ${ }^{7}$. In Canon 15, he also adds performing magic and divination, working as a claqueur to arouse the enthusiasm of the crowds, manufacturing of talismans, and usury ${ }^{8}$. Clearly, he lists professions which Christians considered immoral, as well as ones associated with violence, magic, and pagan beliefs. Being accepted into the Christian community was predicated on abandoning any such profession.

An interesting passage from the second part of Canon 12, regarding the author's expectations from those catechumens who worked as school teachers, deserves to be discussed separately. In the Apostolic Tradition, it is recommended that teachers

${ }^{5}$ Can. Hipp., 10, p. 362, 363.

${ }^{6}$ Can. Hipp., 10, p. 362, 363.

${ }^{7}$ Can. Hipp., 12, p. 364-365.

${ }^{8}$ Can. Hipp., 15, p. 368-371. 
should abandon their occupation; however, as a last resort, if they were unable to find a different livelihood, they were allowed to continue working in that profession $^{9}$. Meanwhile, Pseudo-Hippolytus postulates that they should also teach the Christian faith alongside classical literature, as well as make their pupils aware that the pagan religion is false. The author likely refers to grammarians ( $\gamma \rho \alpha \mu \mu a t i \kappa o ́ c)$, who taught proper language, declension, conjugation etc., but also explained tropes and figures used in poetic works ${ }^{10}$. The stance of the Apostolic Traditions was relatively moderate: in fact, many $3^{\text {rd }}$-century Christian moralists were prepared to reject the heritage of ancient literature in its entirety, considering it dangerous for the shaping of strong faith ${ }^{11}$. However, the author of the Canons of Hippolytus, writing with the perspective of the first half of the $4^{\text {th }}$ century in mind, saw in this profession an opportunity for evangelical work. According to him, teaching children correct grammar and the basics of literature could be combined with familiarizing them with the foundations of Christian beliefs. Regrettably, we are not in a position to ascertain whether such a form of evangelisation indeed took place at all during the first half of the $4^{\text {th }}$ century, and if so, whether it was effective. It would have undoubtedly involved the risk of the loss of employment if the children's parents turned out unhappy with the attempts at converting their children. Nonetheless, in such a situation, the catechumen-teacher would have been able to count on support from his community.

Pseudo-Hippolytus expected that during the first stage of becoming familiar with the Christian lifestyle the catechumens would begin to adapt to the requirements of a moral nature. In Canon 15, he explains that baptism should not be bestowed on those who live promiscuously, prostitute themselves, torment others (e.g. slaves), make false promises, or are hypocrites insulting others with slander. The author advises particular caution towards those who have these faults and bad habits: he argues that people do not change quickly, as this requires strength of character ${ }^{12}$. He is undoubtedly right about that, likely having witnessed himself how some people returned to their old ways after baptism. Following the Apostolic Tradition, the author repeats the prohibition of baptising slaves whose owners are pagan and oppose conversion. Such people had to be satisfied with being among the catechumens ${ }^{13}$. This not only highlighted the respect for the right of ownership, but was also likely intended to avoid antagonising the owners towards Christians:

\footnotetext{
${ }^{9}$ Hippolyte de Rome, La Tradition Apostolique d'après les anciennes versions, 16, trans. B. Botte, ${ }^{2}$ Paris 1968 [= SC, 11bis] (cetera: Trad. ap.), p. 70, 71.

${ }^{10}$ Cf. T. Morgan, Literate Education in the Hellenistic and Roman Worlds, Cambridge 1998, p. 156189; R. Cribiore, Gymnastic of the Mind. Greek Education in Hellenistic and Roman Egypt, Princeton 2001, p. 185-219.

${ }^{11}$ Such views are represented by Tertullian, cf. The Apostolic Tradition. A Commentary, ed. P.F. BRADSHAW, M.E. Johnson, L.E. Phillips, Minneapolis 2002, p. 94, an. 5.

${ }^{12}$ Can. Hipp., 15, p. 368-371.

${ }^{13}$ Can. Hipp., 10, p. 362, 363.
} 
after all, the owners could potentially be converted too. In addition, a slave in such a position would not have been able to fulfil the duty of regularly attending services or to become fully engaged in the life of the community. Of course, remaining a catechumen for life meant that such the person in question could never receive the Holy Communion; nonetheless, in the eyes of their community, they would have kept the faith.

Canon 19 sheds light on the forms of Christian activities which were required of the candidates during the initial period of the catechumenate: these were associated with charitable work, specifically visiting the sick and giving alms to the poor $^{14}$. However, during the $4^{\text {th }}$ century, many catechumens would extend this period of Christian initiation indefinitely. Because of this, bishops appealed to them not to wait ${ }^{15}$. A well-known example of a convert who only received baptism at his deathbed is Emperor Constantine himself ${ }^{16}$.

The second stage of the catechumenate began when the candidate expressed readiness for accepting baptism. Pseudo-Hippolytus furnishes a few details on this subject. The decision that the candidate was ready required the testimony of three people, who needed to confirm the catechumen's Christian lifestyle ${ }^{17}$. Subsequently, the candidate deepened their knowledge of the faith through receiving catechesis, delivered either by the bishop or by a priest who was prepared for the task. Once it was clear that the attendees had mastered the principles of faith, they were allowed to be baptised ${ }^{18}$. In Canon 19, the author specifies that all of the catechumens (from one diocese) ought to gather together and receive instruction from the same teacher ${ }^{19}$. It should be noted that the forty-day tutoring period referred to by Pseudo-Hippolytus is consistent with the usual practice in the East during his times $^{20}$. Meanwhile, in the Apostolic Tradition, on which he based his work, the stipulated preparatory period lasts for as much as three years ${ }^{21}$. The fact that the author of the Canons of Hippolytus updated this information shows that the collection does, to some extent, reflect the reality with which he was familiar. Nevertheless, it

\footnotetext{
${ }^{14}$ Can. Hipp., 19, p. 376, 377.

${ }^{15}$ Cf. Basilius Magnus, Homilia exhortatoria ad sanctum baptisma, [in:] PG, vol. XXXI, col. 423 444; Gregorius Nyssenus, De iis qui baptismum differunt, [in:] PG, vol. XLVI, col. 416-432.

${ }^{16}$ Cf. Eusebè de CÉSArée, Vie de Constantin, IV, 61-64, trans. M.-J. RondeAu, Paris 2013 [= SC, 559], p. 528-535; A.H.M. Jones, Constantine and the Conversion of Europe, Toronto 1987, p. 195200; H.A. Drake, Constantine and the Bishops. The Politics of Intolerance, Baltimore-London 2002, p. 307,308 .

${ }^{17}$ Can. Hipp., 15, p. 370, 371.

${ }^{18}$ Can. Hipp., 12, p. 364, 365.

${ }^{19}$ Can. Hipp., 19, p. 384-387.

${ }^{20}$ The forty-day long preparatory period was described in the greatest detail by the pilgrim Egeria, who visited Jerusalem towards the end of the $4^{\text {th }}$ century; cf. ÉGÉRIE, Journal de voyage, 45,46 , trans. P. Maraval, Paris 2002 [= SC, 296], p. 304-313.

${ }^{21}$ Trad. ap., 17, p. 74, 75.
} 
by no means solves all the problems related to the scholarly research on the subject. It is known that in the East, during the $4^{\text {th }}$ century, candidates who wished to be baptised would express their desire at the beginning of Lent (specifically, on the first Sunday thereof). If they were deemed worthy, their names were written down in the church documents; thus they began their forty days of preparation, after which they were baptised during Easter. It seems, however, that the practice described by Pseudo-Hippolytus does not in fact relate to Lent. The arguments on this matter provided by the editor of the French edition of the Canons of Hippolytus, René-Georges Coquin, are rather convincing ${ }^{22}$. The scholar demonstrates that the aforementioned catechisation could not have taken place during Lent, while the description of the baptism ceremony indicates that it did not occur during Easter either. Based on the analysis of the rules set down by PseudoHippolytus, Coquin observes that the catechumens were allowed to bathe and eat until they were sated during the Thursday before the baptism, which would have been unthinkable during the Holy Week. He also draws attention to the fact that, according to the instructions, the baptism of female catechumens who were undergoing menstruation was to be moved to a different date ${ }^{23}$. We know that baptism was bestowed at two times each year in the first three centuries: during Easter and during Pentecost ${ }^{24}$. Perhaps Pseudo-Hippolytus' description attests to baptism being administered in Egypt more frequently; it may have been related to the local practice of baptising little children. The earliest direct evidence for this comes from the $3^{\text {rd }}$ century; however, it is known that the practice in fact predates that time ${ }^{25}$. Our author also confirms this, recommending (in Canon 19) that the children's baptism should take place before the other catechumens are submerged in the font ${ }^{26}$. Jean Gaudemet also believes that the gradual disappearance of the Easter baptism was associated with the baptism of small children - he notes that the local communities performed the rite during Christmas, Epiphany, the Feast

${ }^{22}$ Cf. Can. Hipp., 12, p. 364, 365, an. 6. On the $4^{\text {th }}$-century practice of baptising during Easter and the Lent catechumenate, cf. T. MAERTEns, Histoire et pastoral du ritual du catéchuménat et du baptême, Bruges 1962, p. 126-129, 146.

${ }^{23}$ We may conclude from Canon 22 that the author of the guidelines regarding the celebration of Easter took into account Jewish customs associated with celebrating Passover; cf. Can. Hipp., 22, p. 388-391. In view of this, it is likely that he allowed the sick to celebrate Easter in the second term, i.e. during Pentecost; $\mathrm{cf}$. Nm, 9, 1-14. It cannot be excluded that the same rule applied to the baptism of women in the above-mentioned cases.

${ }^{24}$ Cf. Tertullianus, De baptismo, 19, [in:] Tertullian's Homily on Baptism, ed. et trans. E. Evans, London 1964, p. 40, 41.

${ }^{25}$ Cf. A.N.S. LAne, Did the Apostolic Church Baptise Babies? A Seismological Approach, Tynd.Bull 55.1, 2004, p. 109-130.

${ }^{26}$ Can. Hipp., 19, p. 378, 379. The author copied this piece of advice from the Apostolic Tradition, cf. Trad. ap., 21, p. 80, 81. 
of the Apostles, or during holidays commemorating particular martyrs ${ }^{27}$. Everett Ferguson refers to a very late, $10^{\text {th }}$ century source from which we learn that the decision to change the frequency of baptism was due to Patriarch Theophilus, motivated by high mortality among children ${ }^{28}$.

\section{Catechumens in north-western Syria}

A comprehensive discussion on the requirements set before catechumens in Syria can be found in the Apostolic Constitutions. In book VIII, the author includes a detailed description of the relevant criteria as well as the admission-related activities. Here, much like in Egypt, the deacons played a certain role during the first meeting between the candidate and the bishop (or the priests). They were the ones who introduced the candidate, also bringing those who vouched for his or her earnest intentions. The prospective catechumen would be questioned about his or her motivations ${ }^{29}$. Ascertaining the reasons behind the desire for baptism was important, since the clergy was careful not to admit those who wavered or those who were still only seeking their religious path. Accordingly, candidates who were to join the Christian community had to meet certain conditions. Thus, the 'qualifying interview' was intended to establish the character of the person with whom the bishop (or priest) were dealing with. The first question that the author advises to settle is whether the candidate is a free person or a slave. If the candidate was a slave, then their potential admission into the catechumenate depended on the approval and positive opinion of their owner. If the owner was a pagan, the candidate was instructed to obtain his goodwill first ${ }^{30}$. Therefore, it is likely that such slaves were refused admission to the catechumenate in Syria ${ }^{31}$.

The initial instruction in the principles of faith also included a discussion concerning the moral laws which should guide all Christians. Accordingly, the clergyman reminded that a catechumen should only be married once, while those who had lived alone until then should get married. There was no consent to informal relationships of any kind, e.g. of an owner with a slave woman. The author of our text stresses that a Christian who maintains carnal relations with a slave should be excommunicated ${ }^{32}$. According to the contemporary practice, and in parallel

\footnotetext{
${ }^{27}$ Cf. J. Gaudemet, L'Église dans l'Empire Romain (IVe-Ve siècle), Paris 1958, p. 61.

${ }^{28}$ E. Ferguson, Baptism in Early Church. History, Theology, and Liturgy in the First Five Centuries, Michigan-Cambridge 2009, p. 699.

${ }^{29}$ Const. ap., VIII, 32, 2, vol. III, p. 234-237.

${ }^{30}$ Const. ap., VIII, 32, 3, vol. III, p. 236, 237.

${ }^{31}$ Unlike in Egypt, where such a slave could remain a catechumen for their entire life. Cf. Can. Hipp., 10 , p. $362,363$.

${ }^{32}$ Const. ap., VIII, 32, 5; 34, 13, vol. III, p. 236, 237, 246, 247. John Chrysostom emphatically opposed the sexual exploitation of slaves. Cf. P. Szczur, Problematyka społeczna w późnoantycznej Antiochii. Na podstawie nauczania homiletycznego Jana Chryzostoma, Lublin 2008, p. 392.
} 
to the situation in Egypt, the author permits accepting an enslaved person who is nearing death to the catechumenate ${ }^{33}$. He subsequently lists the occupations and professions which the candidates should abandon if they want to become catechumens. Differently than Pseudo-Hippolytus, he states categorically that if they do not change their occupation, they will be rejected. We may guess that the candidates were given some time to make the necessary adjustments; after the set period had passed, they were likely scrutinized to confirm whether the required change had indeed occurred. Among the forbidden professions we find the most obvious ones, such as pimp, prostitute, manufacturer of idols, actor, circus driver, gladiator, runner, games organiser, athlete, piper, citharist, lutist, dancer, and innkeeper ${ }^{34}$. Soldiers were to be given a condition: they should be satisfied with their pay alone, and not harm anyone ${ }^{35}$. Therefore, a soldier who became a Christian did not have to abandon his profession - unlike sportsmen, musicians, gladiators, innkeepers, and many others. Nonetheless, they were not allowed to inflict injury on anyone. This prohibition likely refers to the practice - common at the time - of using violence when forcefully acquiring accommodation and food, of looting houses, etc., all of which caused suffering to the local people. There is no indication, however, that the prohibition also applied to killing in $\operatorname{combat}^{36}$. As regards users of magic, diviners, and those who participated in pagan mysteries, as well as those who were known for their immoral lifestyle, the author advises for them to be observed for a prolonged period; if they persisted in these pursuits, they were to be rejected ${ }^{37}$.

\footnotetext{
${ }^{33}$ Const. ap., VIII, 32, 6, vol. III, p. 236, 237. Cf. an. 25, 26.

${ }^{34}$ Const. ap., VIII, 32, 7-9, vol. III, p. 236, 237.

${ }^{35}$ Const. ap., VIII, 32, 10, vol. III, p. 238, 239. The quoted rule clearly refers to the fragment of Lc, 3,14 .

${ }^{36}$ Georges Minois (Kościół i wojna. Od czasów Biblii do ery atomowej, trans. A. Szymanowski, Warszawa 1998, p. 45, 46) points out that the military service lasted for a long time, usually about twenty years. Since it was voluntary, it was a path most often chosen by men from the lower social strata. Soldiers were not allowed to marry; therefore, they often sought the services of prostitutes or maintained concubines. Their pay was low, and life in the camp was devoid of variety and entertainment. During the $4^{\text {th }}$ century, recruitment extended to the borderland barbarians; during the movement of troops, there were incidents of violence towards the local populace, which was often forced to provide accommodation. Cf. A. Śwı̨̨Toń, Przymusowy kwaterunek wojskowy w IV $i$ Vw n.e. i zwiqzane z nim nadużycia, [in:] Contra Leges et Bonos Mores. Przestępstwa obyczajowe w starożytnej Grecji $i$ Rzymie, ed. H. Kowalski, M. KuryŁowiCz, Lublin 2005, p. 343-350. If the rule under discussion were to be examined in the light of the author's earlier arguments, then the infliction of harm (mainly towards the relatives of the victim) would be the killing of an innocent person. However, such harm would not be caused by the killing of an enemy who invaded the country and was threatening the Christian order (Const. ap. VII, 2, 8; VIII, 12, 42, vol. III, p. 28, 29, 200, 201). This, in our opinion, was the meaning of the rules concerning military service included in the Apostolic Constitutions. Consequently, a soldier who was a Christian could fulfil his service with clear conscience for the benefit of all.

${ }^{37}$ Const. ap., VIII, 32, 11, vol. III, p. 238, 239. On the attitude of the author of the Apostolic Constitutions towards magic and those who practised its various forms, cf. A. BAron, Magia i czary
} 
The author also forbids living in concubinage, practising Jewish or pagan customs, and indulging in pastimes associated with violence, as well as games ${ }^{38}$.

Book VIII tells us that the catechumenate was to last for three years. Thus, the author harks back to the guidelines delineated in the Apostolic Traditions, which he used when editing this part of his work ${ }^{39}$. As we have already learned, however, in the $4^{\text {th }}$ century the tendency to postpone baptism by many years had become established in the East. In addition, as we saw, other sources indicate that the period of catechesis became shortened to forty days immediately prior to baptism. Still, it cannot be ruled out that the Apostolic Constitutions describes the practice observed in Syria. The collection known as Testamentum Domini Nostri Jesu Christi, most likely compiled in that region during the $5^{\text {th }}$ century, also only allows baptism to be performed after a three-year period of catechumenate ${ }^{40}$. Another possibility is that our author thought that the pre-baptism preparatory period as customarily observed in his times was too short. He did not, however, see any contraindications to baptising a particularly eager catechumen sooner ${ }^{41}$. Nonetheless, he undoubtedly considered it crucial that the catechumens change their previous lifestyle into that suitable for a Christian in due time. The author of the Apostolic Constitutions does not narrow down the schooling of the catechumens to Lent alone. We do know, however, that in Antioch, which is where the Apostolic Constitutions were written, the catechetic preparations for baptism during the second half of the $4^{\text {th }}$ century lasted thirty days, and began during Lent ${ }^{42}$. In book V, we find a confirmation of the fact that baptism occurred during Easter ${ }^{43}$; the author does not specify whether it could also be administered at other times, however.

Book VII outlines the fairly large body of knowledge that every catechumen had to master before being baptised. This included the teachings about the Holy Trinity, the events of the Old and the New Testament, as well as a commentary on the significance of Christ's salutary activity. It is worth noting, however, that - in book VIII - the author allows the role of the instructor to be fulfilled by

w Konstytucjach apostolskich, [in:] Zabobony, czary i magia w Kościele starożytnym, ed. M. OżóG, N. Widok, Opole 2013 [= OBT, 138], p. 75-95.

${ }^{38}$ Const. ap., VIII, 32, 12-15, vol. III, p. 238, 239.

${ }^{39}$ Const. ap., VIII, 32, 16, vol. III, p. 238, 239; Trad. ap., 17, p. 74, 75.

${ }^{40}$ Testamentum Domini Nostri Jesu Christi, II, 3, ed. I.E. Rahmani, Moguntiae 1899, p. 116, 117. On the basis of the Apostolic Constitutions and the fragment of Testament of Our Lord quoted here, Pietro Rentinck is inclined to think that the catechumenate in Antioch and in Syria lasted from two to three years. Cf. P. Rentinck, La cura pastorale in Antiochia nel IV secolo, Roma 1970 [= AGr.SFHE, sectio B, 178], p. 38 .

${ }^{41}$ Const. ap. VIII, 32, 16, vol. III, p. 238-241.

${ }^{42}$ P. Rentinck, La cura..., p. 38.

${ }^{43}$ Const. ap., V, 19, 3, vol. II, p. 270, 271. Roman Murawski concluded that the Apostolic Constitutions lacked a link between the celebration of baptism and Easter - a view clearly contradicted by this fragment. Cf. R. Murawski, Historia Katechezy. Katecheza w pierwszych wiekach, Warszawa 2011, p. 253, 255. 
a layperson. This had to be a man with experience in teaching, leading a worthy life. Meanwhile, we do know that during the $4^{\text {th }}$ century in the East, catechumens were instructed in churches by bishops and priests. We are unable to say why the author allows a deviation from this practice.

In book VIII, the author quotes a prayer said for the catechumens prior to their departure from the church, ahead of the Eucharist. In it, we find important information regarding the rigours of the Church discipline to which the catechumens were subjected. The author stresses that none of the so-called "listeners" or "unbelievers" may be present while the prayer is said ${ }^{44}$. The latter were likely those who had not yet joined the ranks of the catechumens. However, in the context of what was required of the candidates for baptism, we are interested in the socalled "listeners" (ákpoá $\mu \varepsilon v o l){ }^{45}$. They were one of the four groups of Christians who had broken the Church law and were required to undergo a public penance ${ }^{46}$. They were allowed to gather in the narthex of the church ${ }^{47}$. If a catechumen committed a serious sin, he or she could not be excommunicated, not being a full member of the community in the first place. Nonetheless, such a deed did not remain without consequences: Canon 5 of the Council of Neocaesarea (314-319) declares that if such a person expresses their regret for the sin along with the group of the "weeping ones", they may become part of the "listeners" 48 . Regarding the catechumens who broke down under persecution and participated in a pagan cult, the Council of Nicaea (325) also dictates that they should join the group of the "listeners" for three years. After that time, they were once again allowed to pray with the catechumens ${ }^{49}$. Sending a catechumen to the group of the "listening" penitents meant that, for a period of time, they were not allowed to put themselves forward for baptism. This leads to another question: what happened if a catechumen committed a forbidden act again during this period? The answer is, again, provided in Canon 5 of the Council of Neocaesarea: in such cases, the 'recidivist' sinner was erased from the list of the catechumen $\mathrm{s}^{50}$. Was being deprived of the status of a catechumen meant as a lifetime punishment, however? Certainly not; such a person was allowed to make further attempts at joining the Christian community

\footnotetext{
${ }^{44}$ Const. ap., VIII, 6, 2, vol. III, p. 150, 151.

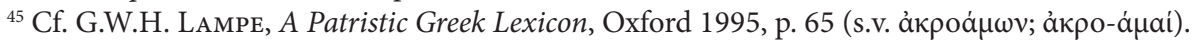

${ }^{46}$ The $4^{\text {th }}$-century Canon 11 ascribes to George the Wonderworker the names of four groups of penitents: crying, listening, lying prostate and standing, cf. Gregorius Thaumaturgus, Canones, 11, [in:] P.-P. Joannou, Discipline générale antique ( $I V^{e}-I X^{e} s$.), vol. II, Les canons des Pères Grecs, Roma 1963 , p. 29, 30. On the types of penitence appropriate for each of these groups, cf. M. CHŁopowieC, Teologia pokuty pierwszych wieków chrześcijaństwa w Kościele wschodnim, RTM 3, 2011, p. 134-140. ${ }^{47}$ Cf. S. ĆurČić, Narthex, [in:] ODB, vol. II, p. 1438-1439.

${ }^{48}$ Canones Synodi Neocesariensis, can. 5, [in:] P.-P. Joannou, Discipline générale antique (IVe $\left.-I X^{e} s.\right)$, vol. I.2, Les canons des Synodes Particuliers, Roma 1962 (cetera: Can. Syn. Neoc.), p. 77.

${ }^{49}$ Concilium Nicaenum I - 325, can. 14, [in:] COGD, vol. I, ed. G. Alberigo, Turnhout 2006, p. 27.

${ }^{50}$ Can. Syn. Neoc., can. 5, p. 77.
} 
if they ceased the forbidden practices. That being said, the matter of when they would be allowed to return to the group of the catechumens most likely depended on the gravity of their transgression and on an attestation that they were following a Christian way of life ${ }^{51}$.

\section{Conclusions}

In the $4^{\text {th }}$ and $5^{\text {th }}$ centuries, catechumens were a very numerous group of Christians in the East. This was no doubt partly caused by the change in the attitude towards Christians on the part of the Roman authorities, leading to the faith being granted the status of religio licita. This also significantly accelerated the Christianisation of the other parts of the Empire, which in turn necessitated the change of the existing procedures regulating the acceptance of catechumens into the community. The period of catechesis was limited to thirty or forty days immediately prior to baptism. The numerous conversions did not always lead to a full-scale change in the way of life into one that was expected of a future Christian, however. As a result, high requirements were put before the catechumens by the authors of pseudo-epigraphic Church regulations. Some of them, following the Apostolic Tradition, instruct the catechumens to abandon certain occupations and activities that were associated with a pagan cult, immoral sexual conduct, forbidden entertainment, or violence. However, since many of the candidates reverted to their old habits after only a brief time, the author of the Apostolic Constitutions advises the return to the three-year period of catechisation. In the $4^{\text {th }}$ century, the faltering candidates were also obliged to undergo a public penance. During a service, they would join the "listening" penitents, who gathered in the narthex of the church; they would leave the temple before the prayer for the catechumens. The Canons of Hippolytus attest that baptism was administered to little children already during that time, with the responsibility for their Christian upbringing resting on their parents or guardians. The rules analysed above reveal the authors' great care for

\footnotetext{
${ }^{51}$ Two interesting rules were adopted at the Council of Elvira (ca. 306?). Canon 45 describes the situation of a former catechumen who did not go to church for a long time; if there were people who could attest that the catechumen nonetheless led a Christian life, he could be baptised. Canon 68, in turn, discusses the case of female catechumens who murdered their newborn children: such women were only allowed to be baptised toward the end of their lives, cf. Concilium Eliberitanum, can. 45, 68, [in:] Sacrorum Conciliorum Nova et Amplissima Collectio, vol. II, ed. J.D. MaNsi, Florentiae 1759 [repr. Paris 1901], col. 13, 17. Of course, we need to remember that the decisions of the Council of Elvira were local in scope. The synod convened during the early $4^{\text {th }}$ century, at a time when there was still no full freedom of Christian worship in the East. Since the council took place soon after persecutions had ended in the West, the bishops were highly rigid regarding certain matters. Nonetheless, Canon 45 does confirm that a former catechumen was allowed to seek baptism once again.
} 
preserving the high standards of the catechumenate at a time when Christianisation was gaining momentum. They knew perfectly well that the quality of the functioning of a Christian community - and therefore the zealous adherence to ecclesiastic rules - depended on the successful shaping of new thought patterns and a novel way of life. For this reason, the authors put such great emphasis on the process of catechisation.

Translated by Michał Zytka

\section{Bibliography}

\section{Primary Sources}

The Apostolic Tradition. A Commentary, ed. P.F. Bradshaw, M.E. Johnson, L.E. Phillips, Minneapolis 2002.

Basilius Magnus, Homilia exhortatoria ad sanctum baptisma, [in:] Patrologiae cursus completus, Series graeca, vol. XXXI, ed. J.-P. Migne, Paris 1857, col. 423-444.

Canones Synodi Neocesariensis, [in:] P.-P. JoAnnou, Discipline générale antique (IVe-IXe s.), vol. I.2, Les canons des Synodes Particuliers, Roma 1962, p. 75-82.

Les Canons d'Hippolyte, ed. et trans. R.-G. Coquin, Paris 1966 [= Patrologia orientalis, 31.2].

Concilium Eliberitanum, [in:] Sacrorum Conciliorum Nova et Amplissima Collectio, vol. II, ed. J.D. Mansi, Florentiae 1759 [repr. Paris 1901], col. 1-20.

Concilium Nicaenum I - 325, [in:] Conciliorum Oecumenicorum Generaliumque Decreta, vol. I, ed. G. Alberigo, Turnhout 2006, p. 19-34.

Les Constitutions Apostoliques, vol. I-III, ed. et trans. M. Metzger, Paris 1985-1987 [= Sources chrétiennes, 320, 329, 336].

ÉGÉRIE, Journal de voyage, trans. P. MARAVAL, Paris 2002 [= Sources chrétiennes, 296].

Eusebè de Césarée, Vie de Constantin, trans. M.-J. Rondeau, Paris 2013 [= Sources chrétiennes, 559].

Gregorius Nyssenus, De iis qui baptismum differunt, [in:] Patrologiae cursus completus, Series graeca, vol. XLVI, ed. J.-P. Migne, Paris 1863, col. 416-432.

Gregorius Thaumaturgus, Canones, [in:] P.-P. Joannou, Discipline générale antique (IVe-IXe s.), vol. II, Les canons des Pères Grecs, Roma 1963, p. 17-30.

Hippolyte de Rome, La Tradition Apostolique d'après les anciennes versions, trans. B. Вотte, ${ }^{2}$ Paris 1968 [= Sources chrétiennes, 11bis].

Tertullianus, De baptismo, [in:] Tertullian's Homily on Baptism, ed. et trans. E. Evans, London 1964.

Testamentum Domini Nostri Jesu Christi, ed. I.E. Rahmani, Moguntiae 1899. 


\section{Secondary Literature}

Baron A., Magia i czary w Konstytucjach apostolskich, [in:] Zabobony, czary i magia w Kościele starożytnym, ed. M. OżóG, N. WidoK, Opole 2013 [= Opolska Biblioteka Teologiczna, 138], p. 75-95.

CHŁopowiec M., Teologia pokuty pierwszych wieków chrześcijaństwa w Kościele wschodnim, "Roczniki Teologii Moralnej” 3, 2011, p. 134-140.

Coquin R.-G., Introduction, [in:] Les Canons d'Hippolyte, ed. et trans. R.-G. Coquin, Paris 1966 [= Patrologia orientalis, 31.2], p. 273-338.

Cribiore R., Gymnastic of the Mind. Greek Education in Hellenistic and Roman Egypt, Princeton 2001.

Ćurčić S., Narthex, [in:] The Oxford Dictionary of Byzantium, vol. II, ed. A. KAZHDAN et al., New York-Oxford 1991, p. 1438-1439.

Drake H.A., Constantine and the Bishops. The Politics of Intolerance, Baltimore-London 2002.

Ferguson E., Baptism in Early Church. History, Theology, and Liturgy in the First Five Centuries, Michigan-Cambridge 2009.

Gaudemet J., L'Église dans l'Empire Romain (IVe-Vé siècle), Paris 1958.

Groppo G., L'evoluzione del catechumenato nelle Chiesa dal punto di vista pastorale, [in:] Valori attuali della catechesi primitiva, ed. S. Felici, Roma 1979, p. 29-49.

Jones A.H.M., Constantine and the Conversion of Europe, Toronto 1987.

Lampe G.W.H., A Patristic Greek Lexicon, Oxford 1995.

Lane A.N.S., Did the Apostolic Church Baptise Babies? A Seismological Approach, "Tyndale Bulletin" 55.1, 2004, p. 109-130.

Laurentin A., Dujarier M., Catéchuménat. Données de l'histoire et perspectives nouvelles, Paris 1969.

Maertens T., Histoire et pastoral du ritual du catéchuménat et du baptême, Bruges 1962.

Metzger M., Introduction, [in:] Les Constitutions Apostoliques, vol. I, ed. et trans. M. Metzger, Paris 1985 [= Sources chrétiennes, 320], p. 13-93.

Minois G., Kościót i wojna. Od czasów Biblii do ery atomowej, trans. A. Szymanowski, Warszawa 1998.

Morgan T., Literate Education in the Hellenistic and Roman Worlds, Cambridge 1998.

Mueller J.G., L'ancien Testament dans l'ecclésiologie des Pères. Une lecture des Constitutions Apostoliques, Turnhout 2004.

Murawski R., Historia Katechezy. Katecheza w pierwszych wiekach, Warszawa 2011.

Rentinck P., La cura pastorale in Antiochia nel IV secolo, Roma 1970 [= Analecta Gregoriana. Series Facultatis Historiae Ecclesiaticae, sectio B, 178].

Szczur P., Problematyka społeczna w późnoantycznej Antiochii. Na podstawie nauczania homiletycznego Jana Chryzostoma, Lublin 2008.

Śwį̨Toń A., Przymusowy kwaterunek wojskowy w IV i Vw n.e. i związane z nim nadużycia, [in:] Contra Leges et Bonos Mores. Przestępstwa obyczajowe w starożytnej Grecji i Rzymie, ed. H. KowaLSKI, M. KuRY£owiCz, Lublin 2005, p. 343-350.

Wipszycka E., Storia della Chiesa nella tarda antichità, trans. V. Verdiani, Milano 2000. 


\begin{abstract}
The article discusses the requirements that $4^{\text {th }}$-century catechumens in the East were expected to meet. Accordingly, the pseudo-epigraphic Church regulations found in the Canons of Hippolitus and in the Apostolic Constitutions are analysed. It can be seen from these texts that their authors showed considerable concern for maintaining high standards associated with the period of the catechumenate; furthermore, they put considerable emphasis on the adherence to the Church regulations and the implementation of Christian standards of thought in daily life.
\end{abstract}

Keywords: late antiquity, early Church, baptism, catechumens, Canons of Hippolytus, Apostolic Constitutions, requirements set for catechumens in the East

Andrzej Rafał Hołasek

Uniwersytet Łódzki

Wydział Filozoficzno-Historyczny

Instytut Historii

Katedra Historii Bizancjum

ul. Kamińskiego 27a

90-219 Łódź, Polska/Poland

aholasek@onet.eu 